\title{
Can Restorative Justice Provide a Better Outcome for Participants and Society than the Courts?
}

\author{
Liam J. Leonard
}

Citation: Leonard, Liam J. 2022. Can Restorative Justice Provide a Better

Outcome for Participants and Society than the Courts? Laws 11: 14. https://doi.org/10.3390/ laws11010014

Academic Editor: Paul Gavin

Received: 25 November 2021

Accepted: 7 February 2022

Published: 14 February 2022

Publisher's Note: MDPI stays neutral with regard to jurisdictional claims in published maps and institutional affiliations.

Copyright: (c) 2022 by the author. Licensee MDPI, Basel, Switzerland. This article is an open access article distributed under the terms and conditions of the Creative Commons Attribution (CC BY) license (https:// creativecommons.org/licenses/by/ $4.0 /)$.
Department of Criminology, Winchester University, Winchester SO22 4NR, UK; liam.leonard@winchester.ac.uk

\begin{abstract}
This article will examine understandings that underpin restorative justice outcomes for participants in order to propose that restorative justice conferences may provide better outcomes for participants than the formal courts of the criminal justice system. The analysis will attempt to shed light on the benefits of the restorative justice conferencing process. These benefits will be shown to include positive individual and community outcomes, which 'restore' participants in a manner which may be closer to concepts of 'justice' than the formal court process.
\end{abstract}

Keywords: restorative; justice; courts; conference; system; victims

\section{Introduction}

This article proposes that a victim-centered and community-orientated approach to justice could possibly provide greater satisfaction with outcomes than the traditional formal approach. Criminal justice employs a system where both the accused and the victim are in some ways marginalized during the various stages of the legal process. This article argues that an approach which focuses on restoring the victims and the offender should be considered. Moreover, the article will discuss the differences in the structures of power within the two systems and how forms of power affect those involved. In so doing, the article will highlight issues of power that have emerged in the formal court system while outlining potential possibilities which may be found within the restorative approach. Essentially, concepts such as guilt, remorse, rehabilitation and desistance through restorative practices will be detailed and contrasted with the formal court system. The article will also present a comparative analysis between formal and informal processes in the criminal justice system to illuminate the potential for achieving victim-orientated outcomes from justice systems. ${ }^{1}$

Restorative justice can be seen as a community movement. We can examine a movement dedicated to restorative justice as a platform for community-based justice. This discussion incorporates the background to the restorative justice movement, outlining intersections between aspects of the restorative justice movement and civil society. Through this approach, the best practices in restorative justice will be emphasized. One of the points within this debate is a recognition of 'justice' as a significant aspect of community development. Furthermore, any debate about justice in the community needs to also recognize the extent that levels of social inequity have had on all levels of society due to increased neoliberalism. This has led to increased levels of privilege and inequality across society. This in turn has created levels of inequality in the criminal justice system.

\section{Theoretical Framework}

This article argues that formal and informal approaches in the criminal justice system provide two competing outcomes in non-professional participants such as juries, victims

1 Some of this discussion has been outlined in Leonard (2021) Global Perspectives on People, Processes and Practice in Criminal Justice Advances in Criminology, Criminal Justice and Penology Series; Hershey PA: US. 
and the accused. These can be characterized as 'social facilitation' (informal) and 'social inhibition' (formal) outcomes. This analysis will contextualize the impact of participation in formal and informal justice processes. For instance, does the formal criminal justice court process allow for a division of labor that facilitates input from non-professionals? Those who comprise the non-professional sections are all corralled into a formal process, whereas the tasks and division of labor within the informal restorative justice setting actually require some social innovation to work (Leonard 2021).

Zajonc's (1965) drive theory of social facilitation provides an indication that some formal processes in an institutional context may lead to the creation of 'social inhibition' in those participating in the processes of justice, including juries, families of victims and victims themselves. On the other hand, informal restorative justice approaches allow for the 'social facilitation' of participants, including the accused. Here, we can see the contract with requirements:

"to be legally and technically correct in a formal context which can be contrasted with the manner in which informal processes may deliver 'socially correct' outcomes which are beneficial to victims, the accused and the wider community" (Leonard 2021).

We can examine Steiner's $(1972,1976)$ 'Three Questions' to ask whether the formal or informal process develops a multifaceted division of labor within the 'Task taxonomy'. One can ask whether the task is divisible or unitary. From this we may surmise that a divisible task is one that benefits from a division of labor, where different people perform different subtasks. We can recognize this process during the following:

Informal Restorative Justice Conferences. A unitary task cannot be divided into subtasks. This is seen in the Formal Criminal Justice court system. Are they maximizing or optimizing tasks? A maximizing task is an open-ended task that stresses quantity: the objective is to do as much as possible, again seen in the formal court system, where CJS professionals are reliant on that system for their living. Optimizing tasks have a set standard: the objective is to meet the standard, neither to exceed nor fall short of it. The standard in informal restorative justice is the satisfaction of participants, and restoration of the community (Leonard and Kenny 2010).

We can ask whether individual inputs are related to the group outcome. This can be seen in the following situations:

- An additive task is one where the group's product is the sum of all the individual inputs. Informal/Restorative Justice

- A compensatory task is one where the group's product is the average of the individuals' inputs. Informal/ Restorative Justice

- A disjunctive task is one where the group selects as its adopted product one individual's input. Formal/Criminal Justice

- A conjunctive task is one where the group's product is determined by the rate or level of performance of the slowest or least able member. Informal Restorative Justice (Victim Orientated) (Leonard 2021)

Finally, a discretionary task is one where the relationship between individual inputs and the group's product is not directly dictated by task features or social conventions; instead, the group is free to decide on its preferred course of action as seen with informal restorative practices.

\section{Civil Society and Restorative Justice}

Essentially, the relationship between civil society and justice can be seen as one which has been embedded in a community-oriented move towards restoration, as opposed to the legal system's overriding concern for retribution. We can locate this process of community healing within the bounds of civil society by establishing which networks are working in 
the field and by identifying the outcomes of the interactions between civil society groups and the agencies of the state. Further understandings of the social, cultural and legal outcomes of the mobilization of the various elements of the restorative justice movement can then be established. As the conceptualization of 'civil society' is itself contested, the four contemporary understandings of 'civil society' set out by Scholte (2007) can be applied to the restorative justice movement. These understandings, which are congruent with the key principles of restorative practices, include the collective human qualities, tolerance, trust and non-violence, a place for community-based political debate, and agencies from the frontline.

\section{4. 'Informal Justice' in the Community}

Restorative justice has played a part in traditional societies, and this can be seen in their histories, including the indigenous peoples of the Americas and Australia and New Zealand. In recent decades the social movements of the counterculture have mobilized in pursuit of social change including mobilization for worker's rights, ethnic and civil rights, feminism, and ecology movements. More recently, the public space has seen mobilization by the Occupy and the anti-globalization movement (Leonard 2008). In many jurisdictions, attempts to create peace, order and community restoration have followed conflict (Leonard 2021).

\section{Restorative Justice Philosophy and Theory}

Restorative Justice is a distinct philosophy of justice, which focuses on making amends for harm done (Wright 1999; Edgar and Newell 2006). Essentially, restorative justice fulfils the basic requirements of the 'social contract' which in the philosophies of Hobbes and Rousseau forms the basis of civil society. The fundamental principle of restorative philosophy is that when a person has harmed another, the most useful response is to try to repair the harm (Consedine 1995; Johnstone and Van Ness 2007). Restorative justice stretches far beyond ideas about criminal justice to encompass civil renewal, individual responsibility, conflict resolution, empowerment, shaming and forgiveness (Braithwaite 1998; Hudson 2003). Whilst the term 'restorative justice' is relatively recent, when reviewed in the context of its historical development it becomes apparent that key terms of restitution, reparation, compensation, reconciliation, atonement, redress, community service, mediation, are all used interchangeably in the literature (Weitekamp and Kerner 2002). These key terms have collectively been united under the umbrella of what is now known as restorative justice.

Restorative justice operates within and outside of the criminal justice process, through policy initiatives and civil society responses (Morris and Maxwell 2002; McCold 2004). Whilst it may have only come to prominence in Western societies in the 1980s, the concept is far from new and can be linked to traditions of the Celts, Maori, Samoans and other indigenous peoples, as well as having roots in various religious communities (Consedine 1995; Gelsthorpe and Morris 2002). For some commentators it is not a new form of justice but rather dates back and returns society to pre-modern forms of justice (Zehr 1990). In this context restorative justice is seen as a traditional community-based process, with the modern criminal justice system as representing inequality of power (Crawford and Newburn 2002). The modern state is considered to have power, and this power is held over communities, victims and offenders. This runs counter to the philosophies of restorative justice (Christie 1977). Braithwaite suggests that community-based restorative justice has been in the approach taken in the process of seeking justice for indigenous peoples across the globe (Braithwaite 1998). Moreover, the re-emergence of restorative justice can be linked to a number of societal and cultural developments. These include movements mobilizing rights alongside an increasing disconnect between the state and civil society. The rise of a power imbalance during the neoliberal era can be said to be reflected in the lack of attention given to victims of crime (Crawford and Newburn 2002).

Daly (2005) outlines the desired outcomes for participants of restorative justice, drawn from her observation of restorative practices: 
(1) Some elements of retributive justice (that is, censure for past offences);

(2) Some elements of rehabilitative justice (for example, by asking, what shall we do to encourage future law-abiding behavior?);

(3) Some elements of restorative justice (for example, by asking, how can the offender make up for what he or she did to the victim?) (Daly 2005, p. 28).

The discussion about the benefits of restorative justice includes a variety of outcomes which can be seen to have multiple benefits across society.

- It substantially reduces repeat offending for some offenders, although not all;

- It reduces repeat offending more than prison for adults and at least as well as prison for youths;

- It doubles (or more) the offences brought to justice as diversions from criminal justice;

- When used as a diversion it helps reduce the costs of criminal justice;

- It provides both victims and offenders with more satisfaction that justice has been done than traditional criminal justice;

- It reduces crime victims' post-traumatic stress symptoms and the related costs;

- It reduces crime victims' desire for violent revenge against their offenders (Sherman and Strang 2007).

Restorative justice in its many forms and in different jurisdictions can now be linked in theory and practice (Shapland et al. 2011). There are now established areas of shared commonality and a tendency to embrace relevant regulatory guidelines such as the $U N$ Basic Principles on the use of restorative justice in criminal matters. These include free consent of participants, which includes victims and offenders, alongside relatives and practitioners. In addition, there is shared agreement about the conference plan, outreach and agreement from participants. Finally, it is accepted practice to follow the approach of using qualified facilitators and to agree to safe space principles between all who take part in any restorative event.

\section{6. "Informal Justice" in Practice}

Essentially, the aim of restorative justice is to highlight the impact of crime on victims and others (Sharpe 1998). Restorative justice also explores community impacts and seeks to restore the role of the community within the system of justice. Amplifying Christie's idea to "let's have as few experts as we dare" (1977, p. 22), restorative justice empowers the victim, offender and families within an informal justice process. According to Crawford and Newburn:

'These are the new stakeholders of a revised vision of justice, which seeks to recognize and bring into play, through their active involvement, a broader conceptualization of the appropriate key actors in dispute processing and resolution' (Crawford and Newburn 2002, p. 22).

Moreover, restorative justice redistributes power away from the formal justice sector, locating it with community stakeholders. These stakeholders then achieve some control over deliberation and decision-making (Hudson 2003). In the case of 'bottom-up' approaches like restorative justice, the relocation of authority from the formal criminal justice system to the informal justice within a community context is key to restructuring systems of justice to foreground the needs of the victim, families and communities which have been damaged by crime.

In addition, the participatory and deliberative processes of restorative justice highlight the significance of participation, empowerment, communication, dialogue and negotiated agreements. Informal environments in which stakeholders are comfortable are conducive to good communication and exchange between parties. In the essence of restorative justice philosophy lies a focus on participatory conflict mediation which focuses on building agreement. This is achieved through a problem-solving approach to crime that is located in local knowledge and local capacity (Johnstone and Van Ness 2007). Restorative justice emphasizes the significance of offenders and victims meeting together in conference settings, and 
restoring a sense of control to these relevant participants is a core aspect of the restorative process (Wright 1999). One further consequence of community-based participation is the restoration of responsibility to participants in order to encourage offenders to be more accountable for their crimes and to encourage others to take responsibility for ensuring the successful implementation of conference outcomes (Morris and Maxwell 2002).

Discussing the consequences of these crimes can become a more powerful way of communicating the impact of their offence to criminals in a manner that highlights impacts on victims (Morris 2002). Restorative justice promotes respect for people and encourages community empowerment. Consequently, it can be more legitimatizing in the eyes of those participating than the traditional justice system. Moreover, restorative justice can create a general respect for the law. In addition, it creates enhanced understandings of the consequences of individual action on victims (McCold 2004). Informal communitybased restorative justice programs encourage participation, empowerment, communication, dialogue and negotiated agreements between parties. Finally, restorative justice leads to particular restorative outcomes, and improves other resolutions such as desistance (Claes and Shapland 2017).

Repairing harm caused by criminality for those affected is a leading aim of restorative justice. Restoration may be symbolic in addition to material, with the intention that outcomes should improve community relationships (Braithwaite 1998). These often include verbal or written apologies, compensation or direct reparation to the victim for the harm and indirect reparation to the community (Hudson 2003). It is suggested that restorative outcomes should be fluid and community-centered as well as problem-oriented (Johnstone 2002). The input and influence of friends and families of the offender and in some cases the response of the victim can shape outcomes and impact desistance from further criminal behavior or activity (Claes and Shapland 2017).

Restorative justice practices have been evolving, and as a result new practices have been applied to different issues including family and educational mediation, workplace training, industrial relations and citizen complaints against the formal criminal justice system. In addition, the spectrum of restorative justice program may be too varied for there to be an agreed definition (Daly 2002). Some restorative justice values and principles are highlighted, while others focus on aims and outcomes or emphasize specific aspects of a program or practice (Hoyle and Young 2002; Hudson 2003). Restorative justice conferencing aims to join rebuild community and individual victims and their families together with offenders and their families and to restore participants and their local communities where possible (Zehr 1990; Bazemore and Walgrave 1999; Braithwaite 1999).

Furthermore, restorative justice has been described as an alternative to formal criminal justice approaches to punishment. From this perspective, restoration is seen as success for all involved, whilst punishment is outlined as a type of failure, as both victim and offender are left unsatisfied with outcomes that are not then beneficial for society overall. This perspective on the potential for restorative justice can be further understood with the following quote from Braithwaite:

"Basically, we should try restorative justice, perhaps again and again; when restorative justice fails, try deterrence, and when deterrence fails, try incapacitation" (Braithwaite 1999, p. 1742).

Gade (2020) has also highlighted the gulf between restorative justice as a viable and different approach to 'justice'. Gade emphasizes the theoretical and practical distinctions between restorative justice, which attempts to mediate between parties to build bridges broken by criminal activity, and the formal criminal justice system, which emphasizes punishment with much less emphasis on community outcomes. This discussion details the disparity between the restorative approach, which can be seen to be focused on both victims and offenders, and the more rigorous and punitive frameworks of the criminal justice system. 


\section{Locating Restorative Justice within Civil Society}

The 'informal' version of the restorative justice movement has its roots in the international initiatives which have created understandings of restorative justice over recent decades. The growth of the modern restorative justice movement has roots within rights perspectives, as promoted by the civil rights and women's movements of the 1960s. The U.S. civil rights movement, for example, was partially rooted in critiques of institutional racism in the American justice system. This critique also framed arguments around the disproportionate imprisonment of minorities. Campaigners for prisoners' rights and alternatives to incarceration can also be seen to emerge from the 'new left' era. Moreover, challenges to formal justice systems emerged in many counties. The feminist movement also provided an important focus on the crimes of rape and violent assaults on women. In addition, women's groups argued for better alternatives to the patriarchal criminal justice system. According to Daly and Immarigeon (1998), feminist organizing and feminist groups were among the first to call attention to the mistreatment of victims in the criminal justice process and prisoners' rights campaigns. These early advocates in the restorative justice movement mobilized around problems for society emanating from an overuse of prisons alongside a lack of recognition for victims in the justice process.

Daly and Immarigeon (1998) have also highlighted the diverse kinds of initiatives which gave rise to the wider mobilization of the restorative justice movement. These included the following initiatives which empowered victims and communities including: prisoner rights and alternatives to prisons; conflict resolution; victim-offender reconciliation programs (VORPs); victim-offender mediation (VOMs); victim advocacy; family group conferences/the 'Wagga' model (FGCs); sentencing circles; victim impact panels (originally established by Mothers Against Drunk Driving or MADD). Varona (1996) links prisoner rights with restorative justice. As with many of the movements that emerged from the counterculture, academic research into justice alternatives ran in parallel (or followed local initiatives) with social movement activism in the pursuit of alternatives to existing justice system practices.

\section{Civil Society and Informal Justice}

To best achieve the potential of civic participation as an informal aspect of the criminal justice system through restorative justice, it is best to locate it within civil society. Civil society includes a range of actors, such as trade unions, development agencies, businesses, advocate groups, universities, academics, the media and local and governmental actors. The role of frontline agencies is important for a civic form of restorative justice to flourish. In addition, the civil society sector incorporates a range of rights-based non-governmental organizations (NGOs) and social movements, including social justice groups, women's rights groups and ethnic and equality advocates. All of these work within the context of an engaged civil society sector that has been given some access to the structures of justice in recent years.

It must be recognized that those advocating for restorative justice have to operate within this dichotomous socio-political culture. Nonetheless, as players within the realm of civil society, those advocating for restorative justice have had some degree of success through the introduction of the concept as an aspect of informal justice practices which overlap at both the institutional and the community levels.

Essentially, restorative justice can be seen as a justice-focused movement for change, and this community-based activity can be found in groups which are linked to civil society, local governance and informal groupings, creating a significant layer of local governmentality. Although lacking the counter-hegemonic basis of other civil society movements, the restorative justice movement is in many ways representative of a radical approach to grassroots governance based on a conceptualization of justice which is embedded in the community (Stenson and Lea 2007). Within this public space, existing notions of punitiveness are challenged in a manner which promotes collective responsibility and inclusive deliberation. The mediation processes of restorative practice can be applied to 
individual, group or community issues, and can be extended out to provide a wider extent of engagement by concerned parties. By providing this extensive and collective range of community-based mediation, the restorative justice movement can address the provision of justice within the parameters of local discourse and situational habitus (Leonard 2021).

The key elements of the informal restorative justice sector can be found within the elements of civil society. These elements incorporate non-governmental organizations (NGOs), agencies and community-based advocates for criminal justice reforms. The various strands within these aspects of third and state sector create a stronger civil society which has the potential to create reforms in criminal justice in the informal sector, making restorative justice a significant layer of contemporary civil society activism. Furthermore, church and pastoral groups have extended the remit of the informal justice sector through restorative justice.

According to Gormally (2006):

"The idea of restorative justice is sweeping through communities. The ideas of restorative justice have formed the core of what has become a real social movement".

The framing processes of the restorative justice movement have suffered from a lack of published material. In turn, this has led to a limited debate about the key issues, influences and direction of the system.

\section{Benefits and Limits of the Informal Justice Process}

The benefits for victims and offenders who take part in restorative justice processes may outweigh those offered by more formal methods, by providing a shared or communitybased platform for dealing with crime and its private and public outcomes such as pain, remorse and guilt. At first, victims are given the opportunity to meet the offender and outline to them their version of events, and how the offence has impacted their lives. Meeting with the offender also gives the victim the opportunity to understand the reason for the offence. Victims may realize that they were not targeted for any personal reasons. The meeting may also empower them to overcome worries about possible re-victimization. Research demonstrates that victims are empowered through restorative justice and may be satisfied by receiving an apology, reparation for the harm caused and an assurance that there will not be a reoccurrence. The community, who can be said to have failed the offender as much as the victim from a Durkheimian or 'anomic' perspective, can also partake in a community-based restoration process.

Restorative conferences provide the offender with the opportunity to take responsibility and account for their actions. The restorative justice process empowers them, allowing offenders to express genuine remorse, and also to apologize directly to the victim. The outcome may see the offender make some form of reparation, possibly financial. It further allows offenders to deal with underlying problems, and also provides them with the opportunity to work with their families and the authorities to fully integrate themselves back into society. Restorative Justice may provide the criminal justice system with an alternative means of dealing with crime control across society, and even within a wider political context, such as post-conflict mediation.

The benefit of restorative justice for society and the criminal justice system is that is has implications for social control in the form of reducing future rates of crime. The juvenile offenders of today are the major criminals of tomorrow. For offenders, restoring a sense of security and empowerment can rebuild their confidence in finding employment and achieving educational and sporting success, and help them feel confident and secure in the future. Restorative justice practices that involve victims and (ex-) offenders can help to maintain and strengthen those ex-offenders' desires to desist (Claes and Shapland 2017).

\section{Community Empowerment}

The restorative justice philosophy involves all of those affected by the criminal behavior, be they victims, offenders, the families involved, or the wider community-all play their part in resolving the issues that flow from the offending. As Braithwaite (2003) 
contends, the restorative justice process empowers all parties to restore the deliberative control of justice by its citizens. The remaining terms of the agreement came about because of dialogue, interaction and agreement between all parties. The community may acknowledge its own failings and address the best outcome through mediation. However, the process can empower the community, who can present their shared grievance in a public forum to key actors from the state or multinationals. With such processes embedded in civil society, the third sector could provide a vital bridge between concerned communities and the de-legitimized state.

Wheeldon (2009) has outlined concerns about the co-optation of the restorative justice movement within the wider socio-political system of justice due to the bridging role restorative justice can play through the links created between civil society and agencies of the state. However, the pitfalls of co-optation can be avoided through the development of a framework which allows the 'third sector' groups of civil society to work with the community-orientated projects of state justice agencies such as the police or probation services. Once established, this creates a vital role for civil society agencies within the criminal justice system, while also providing a forum for the presentation of community grievances. In essence, the establishment of informal frameworks provides communities and victims with a degree of access to the 'political opportunity structures' of both the justice system and the wider political frameworks surrounding any dispute. The community conferencing outlined can subsequently be seen to represent a 'political mediation model' based on 'transformative mediation' (Bush and Folger 1994).

The restorative justice movement provides an opportunity to achieve a fairer and more satisfactory criminal justice system for all members of society. In this way, the 'gaps' which exist in the provision of justice through civil society participation in alternative forms of policing through conferencing is established. Restorative justice principles are slowly being accepted as alternatives to sentencing and as a community or individual mediation process in the community. There is a growing acknowledgement among professionals and academics that society needs to develop other responses to crime. The restorative justice process has much to offer by way of community initiatives, as focusing on the greater use of non-custodial sentences will not only bring about changes in the community's relationship with the law but will have significant implications for improved and deeper methods of providing social justice.

These restorative measures improve the context of policing and crime prevention in the community and enhance the processes of justice across society. Through rehabilitation and reintegration rather than traditional punitive measures, offenders come to realize that there is nothing to be gained from leading a life of crime. Ultimately, as an alternative system of policing the community, restorative justice provides a significant alternative based on concepts of sustainable justice rather than short-term punitiveness. History demonstrates that if we continue to use a criminal justice system oriented principally towards forms of punishment based on vengeance, then society will continue to suffer cycles of recidivism and higher rates of crime.

\section{How Does Restorative Justice Improve Outcomes for the Community?}

According to research undertaken in 2012 by the Criminal Justice Joint Initiatives, restorative justice can be shown to help victims to recover whilst also allowing offenders to understand the impact their crimes have on the victim and the community. It also provides the offender the opportunity to make amends for their actions. The report looked at a sample of police forces, probation trusts, youth offending teams and prisons/young offender institutions to gain insights into the use of restorative justice by frontline agencies.

The 2012 report found that there were good satisfaction ratings for restorative justice amongst the three main sections involved. Victims reported high satisfaction ratings. Offenders reported that restorative justice had influenced them in a positive way. Moreover, the members of the public who were interviewed provided positive support for restorative practices, particularly for young people (Criminal Justice Joint Initiatives 2012). The report 
did find that there was a need to involve communities more integrally with any restorative events to increase public confidence in such practices.

The Report put forward eleven recommendations to improve and promote the use of restorative justice in the community. These include the National Offender Management Service and later Her Majesty's Prison and Probation Service, ensuring that there is a national strategy, the development of a national out-of-court disposals framework, further research into victim satisfaction and reduction of offending rates, while developing an evidence base of what works in the field. Furthermore, the report called for increased consultation with relevant parties, increased training, awareness, consistency and further engagement with youth panels (Criminal Justice Joint Initiatives 2012).

In addition, Stefanovska (2013) finds that restorative justice has many benefits for the community. These include a reduction in re-offending by those who have participated in restorative conferences. Maxwell and Morris (1993) have identified the community benefits found in restorative justice approaches which allow an offender to find support from family and community members, which helps build pathways to rehabilitation in a way that the formal court system fails to do. Other community benefits include freeing up valuable court time. According to Stefanovska (2013): restorative justice reduces judicial waiting times for cases diverted to restorative conferences. Justice outcomes can thereby be expedited in both the formal and informal systems, and case loads can be reduced accordingly. This, in addition to the benefits to the victims who are given a role and a say in the restorative processes, leads to increased satisfaction with justice outcomes at a time when the formal justice institutions face public scrutiny due to a loss of public confidence across the justice sector generally.

\section{Limitations of Restorative Justice}

There are also some limitations to what restorative justice can achieve in society and these have been set out by a variety of restorative justice scholars. Van Ness (1997) for example has noted that criticisms of restorative justice can present something of a challenge to the formal justice system and may even undermine that formal system in some ways. In addition, the final outcome of restorative processes takes longer to achieve and it can lack the certainty that the formal court systems provide. Satisfaction with outcomes can vary among victims and their families, creating further discord. This can be seen in serious crime cases. Families may be divided on outcomes in a murder case; it is very difficult for the victim's family to participate in a conference with the offender or offenders. In the case of restorative conferences organized by religious groups, the desire to forgive the offenders may play a large part in the process. In addition, the location of informal restorative justice outside the formal criminal justice system can create a sense of doubt about the legal status of the outcome of any restorative event. Furthermore, Daly $(2006,2016)$ has noted that the lack of an agreed upon definition of what restorative justice actually is can cause problems. This has been repeated in a wide range of research and it remains an enduring concern. Daly also notes that a genuine and sincere apology can be difficult to achieve. These factors can result in it being easier to achieve fairness than restoration in a restorative justice process. Daly suggests that modest outcomes should be the objective rather than seeking a promised land of restorative justice nirvana.

\section{Conclusions}

The restorative justice movement can be seen to have an impact in the areas of community development, civil society, governmentality and policy delivery. This occurs on two levels; the first is at the level of extending the remit of the state through civil society's engagement with community policing in the form of the various conferencing initiatives. The second impact reflects a more controversial perspective. Such contention is demonstrated through the capacity of restorative justice to serve as a facilitator of community empowerment which strengthens civil society and third sector engagement, creating a form 
of social capital which has true implications for the establishment of a broader and more inclusive justice base across society.

The mobilization of any social movement has limited potential to secure complete social or cultural change in the area of contention chosen by its advocates as the social issue requiring attention. No movement can completely restore the loss suffered as a result of any injustice which occurs. Nonetheless, this article demonstrates that the informal restorative justice movement can contribute to an active civil society by creating the conditions whereby certain outcomes which are compatible with the movement's aims are achieved. These outcomes include the following:

The amelioration of grief and suffering in the community, the creation of networks which facilitate dialogue between opposing parties, strengthening of civil society through the facilitation of processes of engagement with the various elements of the justice system such as the police, courts and welfare services, extension of the concept of justice beyond that of punishment, creating a deeper form of sustainable justice throughout society, and the creation of 'sustainable justice' in society (Leonard and Kenny 2010).

The restorative justice movement is aligned with the framework for civil society set out by Scholte's (2007) civil-society-orientated criteria of creating public space for discussion, tolerance, associational living and the engagement of the third sector in society. Furthermore, the restorative justice movement can provide a bridge between civil society and the justice system through the provision of restorative conferencing in community-based disputes. As we have seen, Gade (2020) highlights the distinctions between restorative justice and criminal justice approaches. For him, the punitive approach of the formal criminal justice system can be seen to be quite distinct from the restorative and community-centered approach of restorative justice.

In addition, the 2012 Criminal Justice Joint Initiatives report outlines many areas where the provision of restorative justice can be enhanced and improved for participants. By introducing the key recommendations of the report, such as extensive public consultation, increased training, building awareness of potentials, developing consistent practices and involving youth panels, the prospects for restorative justice to provide a viable alternative to the formal criminal justice system can be achieved. This should see the promotion of restorative justice as a partner with the formal system of justice, rather than a competitor to existing approaches. This would improve community satisfaction with the potential to achieve justice and restoration at the community level.

According to Wheeldon (2009), "The restorative justice project is challenged today by a desire both from within and outside the movement to more fully engage with the criminal justice system". This demonstrates that while the risks of co-option are real for the restorative justice movement, the processes of restorative justice hold out a much deeper promise of providing a real alternative to narrow punitive or the cycles of negativity that characterize many social or criminal disputes. In many ways, the restorative conferencing established by the police provides the type of access to politics required by both communities and the state in the pursuit of full mediation and the resolution of publicly held grievances.

The informal nature of restorative justice can also help to rebuild social bonds and 'values'. These values provide us with a framework with which to understand restorative justice as something which moves beyond the punitive outcomes of the formal criminal justice system. These values are outlined as including:

- A peaceful social life. Peace means more than the absence of open conflict.

- The second normative value is respect. All people are treated as worthy of consideration, recognition, care and attention simply because they are people.

- The third normative value is solidarity. This refers to the feeling of agreement, support and connectedness among members of a group or community.

- The final normative value is active responsibility. Active responsibility arises from within a person; passive responsibility is imposed from outside the person (Sherman and Strang 2007). 
These values can provide community and civic outcomes which are beneficial for society, in a manner that mirrors the bonding aspects of social capital. These outcomes go far beyond those of the punitive criminal justice system, which fails to address wider social requirements. Moreover, restorative conferencing can provide an alternative to disputes about the provision of social justice, whether in areas such as community participation in policing and judication processes or the creation of a positive and neutral space for social expression and dialogue on different levels (including protests) through public conferencing. This creation of a 'political mediation model' is based on 'transformative mediation' (Bush and Folger 1994).

This 'transformation' (or 'innovation' for movement theorists) addresses what Bush and Folger (1994) refer to as the 'destabilizing' of relationships through conflict, transforming relations through processes of mediation and the development of mutual understandings by all parties. The processes of transformative mediation discussed here use the creation of dialogue as a measure of success, rather than the successful attainment of preconceived outcomes, which may jeopardize the attainment of full restoration within the community. Therefore, the potential for restorative justice as a viable alternative for the formal court system within a traditionally patriarchal criminal justice system is certainly something which allows communities to reengage with the processes of justice in a meaningful way.

Funding: This research received no external funding.

Institutional Review Board Statement: Not applicable.

Informed Consent Statement: Not applicable.

Data Availability Statement: Not applicable.

Conflicts of Interest: The authors declare no conflict of interest.

\section{References}

Bazemore, Gordon, and Lode Walgrave, eds. 1999. Restorative Juvenile Justice. Monsey: Criminal Justice Press.

Braithwaite, John. 1998. 'Restorative Justice'. In Handbook of Crime and Punishment. New York: Oxford University Press.

Braithwaite, John. 1999. A future where punishment is marginalized: Realistic or utopian? UCLA Law Review 46: 1727-50.

Braithwaite, John. 2003. Does Restorative Justice Work? In A Restorative Justice Reader: Texts, Sources, Context. Edited by Gerry Johnstone. Devon: Willan Publishing, pp. 320-52.

Bush, R. Robert Baruch, and Joseph P. Folger. 1994. The Promise of Mediation. San Francisco: Jossey-Bass.

Christie, Nils. 1977. Conflicts as property. British Journal of Criminology 17: 1-15. [CrossRef]

Claes, Bart, and Joanna Shapland. 2017. Desistance from crime and restorative justice. Restorative Justice 4: 302-22. [CrossRef]

Consedine, Jim. 1995. Restorative Justice: Healing the Effects of Crime. Lyttelon: Ploughshares Publications.

Crawford, Adam, and Tim Newburn. 2002. Recent Developments in Restorative Justice for Young People in England and Wales: Community Participation and Representation. British Journal of Criminology 42: 476-95. [CrossRef]

Criminal Justice Joint Initiatives. 2012. Criminal Justice Joint Initiatives Report. Facing Up To Offending: Use of Restorative Justice in the Criminal Justice System. A Joint Thematic Inspection by HMIC, HMI Probation, HMI Prisons and the HMCPSI. London: Criminal Justice Joint Inspectorate.

Daly, Kathleen, and Russ Immarigeon. 1998. The past, present, and future of restorative justice: Some critical reflections. The Contemporary Justice Review 1: 21-45.

Daly, Kathleen. 2002. Restorative Justice: The Real Story. Punishment and Society 4: 55-79. [CrossRef]

Daly, Kathleen. 2005. Restorative versus Retributive Justice. The Centre for Crime and Justice Studies 60: 28-37. [CrossRef]

Daly, Kathleen. 2006. The Limits of Restorative Justice. In Handbook of Restorative Justice: A Global Perspective. Edited by Dennis Sullivan and Larry Tifft. New York: Routledge.

Daly, Kathleen. 2016. What is restorative justice? Fresh answers to a vexed question. Victims and Offenders 11: 9-29. [CrossRef]

Edgar, Kimmett, and Tim Newell. 2006. Restorative Justice in Prisons: A Guide to Making It Happen. Winchester: Waterside Press.

Gade, Christian. 2020. Is restorative justice punishment? Conflict Resolution Quarterly 38: 28-46. [CrossRef]

Gelsthorpe, Loraine, and Allison Morris. 2002. Restorative youth justice the last vestiges of welfare? In Youth Justice Critical Readings. Edited by John Muncie, Gordon Hughes and Eugene McLaughlin. London: Sage.

Gormally, B. 2006. Community Restorative Justice in Northern Ireland: An Overview. Restorative Justice Online. Available online: http:/ / www.restorativejustice.org/editions/2006/april06/gormallyarticle (accessed on 10 January 2022). 
Hoyle, Carolyn, and Richard Young. 2002. Restorative Justice: Assessing the prospects and pitfalls. In The Handbook of the Criminal Justice Process. Edited by Mike McConville and Geoffrey Wilson. Oxford: Oxford University Press.

Hudson, Barbara. 2003. Understanding Justice, 2nd ed. Berkshire: McGraw-Hill Education Open University Press.

Johnstone, Gerry. 2002. Restorative Justice: Ideas, Values, Debates. Cullompton: Willan Publishing.

Johnstone, Gerry, and Daniel W. Van Ness. 2007. The meaning of restorative justice. Handbook of Restorative Justice 5-23. Available online: http:/ / students.aiu.edu/submissions/profiles/resources/onlineBook/H4S8j2_Restorative_Justice.pdf\#page=28 (accessed on 10 January 2022).

Leonard, Liam. 2008. The Environmental Movement in Ireland. Dordrecht: Springer.

Leonard, Liam, and Paula Kenny. 2010. Sustainable Justice. Advances in Ecopolitics Series 6; Bradford: Emerald.

Leonard, Liam, ed. 2021. Global Perspectives on People, Processes and Practice in Criminal Justice. Advances in Criminology, Criminal Justice and Penology Series; Hershey: IGI Global.

Maxwell, Gabrielle M., and Allison Morris. 1993. Families, Victims and Culture: Youth Justice in New Zealand. Wellington: Department of Social Welfare and Institute of Criminology.

McCold, Paul. 2004. What is the role of community in Restorative Justice Theory and Practice? In Critical Issues in Restorative Justice. Edited by Howard Zehr and Barb Toews. Monsey: Criminal Justice Press and Devon, Willan Publishing.

Morris, Allison. 2002. Critiquing the critics: A brief response to critics of restorative justice. British Journal of Criminology 42: 596-615. [CrossRef]

Morris, Allison, and Gabrielle Maxwell, eds. 2002. Restorative Justice for Juveniles: Conferencing, Mediation and Circles. Oxford: Hart Publishing.

Scholte, Jan Aart. 2007. Global civil society-Opportunity or obstacle for democracy. In Global Civil Society: More or Less Democracy. Development Dialogue No. 49. Upsaala: Dag Hammarskjöld. Available online: https://www.econbiz.de/Record/global-civilsociety-opportunity-or-obstacle-for-democracy-scholte-jan-aart/10003610137 (accessed on 10 January 2022).

Shapland, Joanna, Gwen Robinson, and Angela Sorsby. 2011. Restorative Justice in Practice. London: Routledge.

Sharpe, Susan. 1998. Restorative Justice: A Vision for Healing and Change. Edmonton: Edmonton Victim Offender Mediation Society.

Sherman, L. Lawrence, and Heather Strang. 2007. Restorative Justice: The Evidence. London: Smith Institute.

Stefanovska, Vesna. 2013. New challenges and perspectives of restorative justice. Balkan Social Science Review 2: 47-62.

Steiner, Ivan Dale. 1972. Group Process and Productivity. New York: Academic Press.

Steiner, Ivan Dale. 1976. Task-performing groups. In Contemporary Topics in Social Psychology. Edited by J. W. Thibaut and J. T. Spence. New York: Academic Press, pp. 393-422.

Stenson, Kevin, and John Lea. 2007. Security, Sovereignty, and Non-State Governance "From Below". Canadian Journal of Law and Society/Revue Canadienne Droit et Société 22: 9-27.

Van Ness, Daniel W. 1997. Legislating for Restorative Justice. Paper Given to the Juvenile Justice International Workshop. Available online: https:/ / biblioteca.cejamericas.org/bitstream/handle/2015/950/legislatingfor.pdf?sequence=1\&isAllowed=y (accessed on 10 January 2022).

Varona, Gema. 1996. Restorative Justice: New Social Rites within the Penal System. Onati: International Institute for the Sociology of Law. Weitekamp, Elmar G. M., and Hans-Jürgen Kerner, eds. 2002. Restorative Justice Theoretical Foundations. Devon: Willan Publishing.

Wheeldon, Johannes. 2009. Finding common ground: Restorative justice and its theoretical construction(s). Contemporary Justice Review 12: 91-100. [CrossRef]

Wright, Martin. 1999. Restoring Respect for Justice. Winchester: Waterside Press.

Zajonc, Robert B. 1965. Social facilitation. Science 149: 269-74. [CrossRef] [PubMed]

Zehr, Howard. 1990. Changing Lenses: A New Focus for Crime and Justice. Scottdale: Herald Press. 